\title{
Spectral correlations and antimicrobial activities of some $(E)-\mathrm{N}$-Benzylidenepyridin-2-amines
}

\author{
S. P. Sakthinathan ${ }^{1}$, R. Suresh ${ }^{1}$, V. Mala ${ }^{1}$, K. Sathiyamoorthi ${ }^{1}$, \\ D. Kamalakkannan ${ }^{1}$, K. Ranganathan ${ }^{1}$, R. Arulkumaran ${ }^{1}$, S. Vijayakumar ${ }^{1}$, \\ R. Sundararajan ${ }^{1}$, G. Vanangamudi ${ }^{1, *}$, G. Thirunarayanan ${ }^{2}$ \\ ${ }^{1} \mathrm{PG} \&$ Research Department of Chemistry, Government Arts College, C-Mutlur, \\ Chidambaram - 608102, India. \\ ${ }^{2}$ Department of Chemistry, Annamalai University, Annamalainagar - 608002, India. \\ *E-mail address: drgvsibi@gmail.com
}

\begin{abstract}
A series of aryl imines have been synthesized by Fly-ash: PTS catalyzed microwave assisted oxidative coupling of amines and aldehydes under solvent-free conditions. The yield of the imines has been found to be more than $90 \%$. The purity of all imines has been checked using their physical constants and spectral data as published earlier in literature. The UV $\lambda_{\max } \mathrm{C}=\mathrm{N}(\mathrm{nm})$, infrared $\nu \mathrm{C}=\mathrm{N}\left(\mathrm{cm}^{-1}\right), \mathrm{NMR} \delta(\mathrm{ppm})$ of $\mathrm{CH}=\mathrm{N}$ and $\mathrm{C}=\mathrm{N}$ spectral data have been correlated with Hammett substituent constants and $\mathrm{F}$ and $\mathrm{R}$ parameters using single and multi-linear regression analysis. From the results of statistical analysis, the effect of substituents on the above spectral data has been studied. The antimicrobial activities of all imines have been studied using Bauer-Kirby method.
\end{abstract}

Keywords: Oxidative coupling Solvent-free synthesis; Fly-ash: PTS; Aryl imines; IR and NMR spectra

\section{INTRODUCTION}

Schiff bases are typically formed by the condensation of a primary amine and an aldehyde. The resultant compound containing functional group $-\mathrm{CH}=\mathrm{N}-$ is called an imine. Imines can also be prepared from ketones but the reaction tends to occur less readily than that with aldehyde. Schiff bases are characterized by the $-\mathrm{N}=\mathrm{CH}-$ (imine) group [1]. The formation of imines involve nucleophilic attack of primary amine on carbonyl carbon affords hydroxyl compound which on dehydration gives Schiff bases.

The formation of Schiff's bases in the second step largely depends upon the rate of removal of water from reaction mixture. Originally, the classical synthetic route for synthesis of Schiff bases was reported by Schiff [2] which involves condensation of primary amines with carbonyl compounds under azeotropic distillation [3] with the simultaneous removal of water. Schiff's bases belong to a widely used group of organic intermediates important for production of specialty chemicals, e.g. pharmaceuticals, or rubber additives [4] and as amino protective groups in organic synthesis [5-6].

They also have uses as liquid crystals [7] and in analytical [8-10] medicinal [9] and polymer chemistry [10]. Due to the great flexibility and diverse structural aspects, a wide range of Schiff's bases have been synthesized and their complexation behaviors have been 
studied.[11] Schiff's bases derived from aromatic amines and aromatic aldehydes have a wide variety of applications in many fields like asymmetric catalysis [12], magnetic properties [13], photochromism [14], binding with DNA [15], construction of supra molecular structures [16], activity against Ehrlichascites carcinoma (EAC) [17], dyes and pigment [18], corrosion inhibitors [19], anti-HIV [20] and physical properties in the crystalline state [21]. Schiff's bases have attracted considerable attention of organic chemists due to their significant biological activities like anticancer [22], antitumor [23], antiinflammatory agents [24], insecticidal [25], antibacterial [26], antituberculosis [27], antimicrobial [28], anticonvulsant [29] activity.

The Schiff bases are also used as versatile components in nucleophilic addition with organometallic reagents [30] and in cycloaddition reactions [31,32]. The effect of substituents on the group frequencies have been studied, through UV-Vis, IR, ${ }^{1} \mathrm{H}$ and ${ }^{13} \mathrm{C}$ NMR spectra of ketones [33] unsaturated ketones [34-36], acid chlorides [37] acyl bromides, and their esters [38].

He effects of substituents on the infrared, proton and carbon-13 group frequencies of Schiff's bases have not been studied so far. Hence the authors have been taken efforts to synthesize substituted benzylidene pyridine Schiff's bases for assessment of their substituent effects by correlation analysis using Hammett substituent constants. The biological activities of these imine derivatives have been studied using Bauer-Kirby [39] method.

\section{EXPERIMENTAL}

\section{1. Materials and Methods}

All the chemicals involved in the present investigation, have been procured from Sigma-Aldrich and E-Merck chemical companies. Melting points of all imines have been determined in open glass capillaries on SUNTEX melting point apparatus and are uncorrected. The UV spectra of all the imines, synthesized, have been recorded with ELICOBL222 spectrophotometer $\left(\lambda_{\max } \mathrm{nm}\right)$ in spectral grade methanol solvent.

Infrared spectra $\left(\mathrm{KBr}, 4000-400 \mathrm{~cm}^{-1}\right)$ have been recorded on AVATAR-300 Fourier transform spectrophotometer. The NMR spectra were recorded in Bruker AV400 NMR spectrometer operating at $400 \mathrm{MHz}$ has been utilized for recording ${ }^{1} \mathrm{H}$ NMR spectra and 100 $\mathrm{MHz}$ for ${ }^{13} \mathrm{C}$ spectra in $\mathrm{CDCl}_{3}$ solvent using TMS as internal standard.

\section{2. Preparation of catalyst}

The Fly-ash: PTS catalyst has been prepared by the procedure published in literature [40]. In a $50 \mathrm{~mL}$ Borosil beaker, $1 \mathrm{~g}$ of fly-ash and $0.8 \mathrm{~mL}(0.5 \mathrm{~mol})$ of $p$-toluenesulphonic acid have been taken and mixed thoroughly with glass rod. This mixture has been heated on a hot air oven at $85{ }^{\circ} \mathrm{C}$ for $1 \mathrm{~h}$, cooled to room temperature, stored in a borosil bottle and tightly capped.

\section{3. Synthesis of imines}

An appropriate equi-molar quantities of aryl amines $(2 \mathrm{mmol})$, substituted benzaldehydes $(2 \mathrm{mmol})$ and Fly-ash: PTS $(0.5 \mathrm{~g})$ have been taken in borosil tube and tightly capped. The mixture has been subjected to microwave irradiation for 6-12 minutes in a microwave oven (Scheme 1) (LG Grill, Intellowave, Microwave Oven, and 160-800 W) and 
then cooled to room temperature. After separating the organic layer with dichloromethane the solid product has been obtained on evaporation. The solid, on recrystallization with benzenehexane mixture gives glittering product. The insoluble catalyst has been recycled by washing with ethyl acetate $(8 \mathrm{~mL})$ followed by drying in an oven at $100^{\circ} \mathrm{C}$ for $1 \mathrm{~h}$ and reused for further reactions. The analytical data of imines are presented in Table 1.

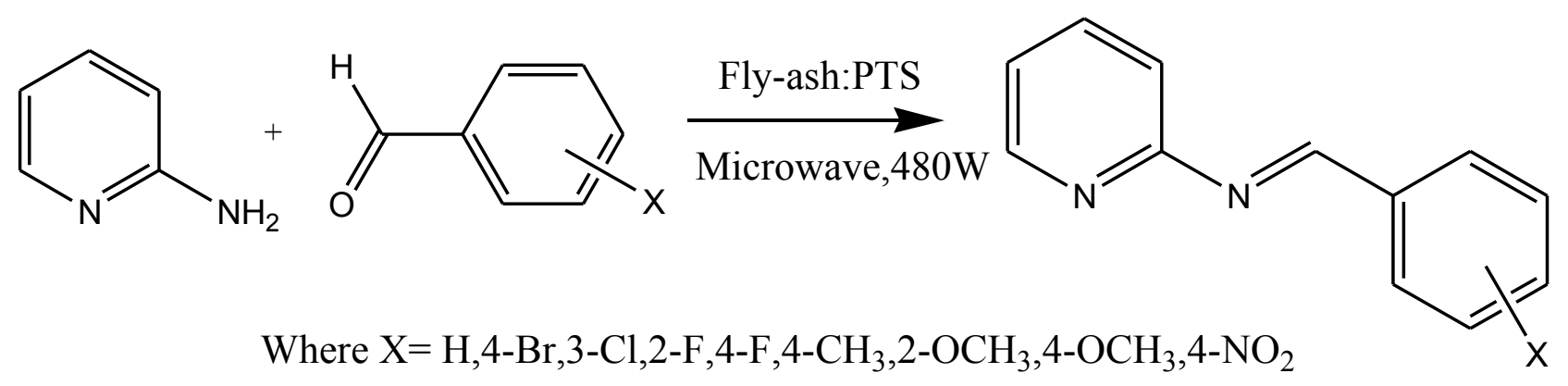

Scheme 1. Synthesis of substituted benzylidenepyridine-2-amines.

Table 1. The yield and physical constants of imines.

\section{RESULTS AND DISCUSSION}

\section{1. Spectral linearity}

In the present study the spectral linearity of synthesized imines has been studied by evaluating the substituent effects. The spectral data observed for the imines, UV $\lambda_{\max }(\mathrm{nm})$,

\begin{tabular}{|c|c|c|c|c|c|}
\hline Entry & $\mathbf{X}$ & M. F. & M. W. & Yield (\%) & m.p. $\left({ }^{\circ} \mathbf{C}\right)$ \\
\hline $\mathbf{1}$ & $\mathrm{H}$ & $\mathrm{C}_{12} \mathrm{H}_{10} \mathrm{~N}_{2}$ & 182 & 82 & $95-96(92-95)[41]$ \\
\hline $\mathbf{2}$ & $4-\mathrm{Br}$ & $\mathrm{C}_{12} \mathrm{H}_{9} \mathrm{BN}_{2}$ & 261 & 89 & $101-102$ \\
\hline $\mathbf{3}$ & $3-\mathrm{Cl}$ & $\mathrm{C}_{12} \mathrm{H}_{9} \mathrm{ClN}_{2}$ & 216 & 90 & $91-92$ \\
\hline $\mathbf{4}$ & $2-\mathrm{F}$ & $\mathrm{C}_{12} \mathrm{H}_{9} \mathrm{FN}_{2}$ & 200 & 92 & $108-109$ \\
\hline $\mathbf{5}$ & $4-\mathrm{F}$ & $\mathrm{C}_{12} \mathrm{H}_{9} \mathrm{FN}_{2}$ & 200 & 85 & $84-85$ \\
\hline $\mathbf{6}$ & $4-\mathrm{CH}_{3}$ & $\mathrm{C}_{13} \mathrm{H}_{12} \mathrm{~N}_{2}$ & 196 & 89 & $120-121(119-122)[41]$ \\
\hline $\mathbf{7}$ & $2-\mathrm{OCH}_{3}$ & $\mathrm{C}_{13} \mathrm{H}_{12} \mathrm{~N}_{2} \mathrm{O}$ & 212 & 91 & $140-141$ \\
\hline $\mathbf{8}$ & $4-\mathrm{OCH}_{3}$ & $\mathrm{C}_{13} \mathrm{H}_{12} \mathrm{~N}_{2} \mathrm{O}$ & 212 & 86 & $156-157(155-157)[41]$ \\
\hline $\mathbf{9}$ & $4-\mathrm{NO}_{2}$ & $\mathrm{C}_{12} \mathrm{H}_{9} \mathrm{~N}_{3} \mathrm{O}_{2}$ & 227 & 90 & $114-115(120-123)[41]$ \\
\hline
\end{tabular}


infrared $v \mathrm{C}=\mathrm{N}$, the proton chemical shifts $\delta(\mathrm{ppm})$, of $\mathrm{CH}=\mathrm{N}$ and carbon chemical shifts of $\mathrm{C}=\mathrm{N}$ are correlated with various substituent constants.

\section{1. $\mathrm{UV}-\mathrm{Vis}$ spectral study}

The measured absorption maxima $\left(\lambda_{\max } \mathrm{nm}\right)$ of synthesized imines are presented in Table 2. These values have been correlated with Hammett substituent constants and F and $\mathrm{R}$ parameters using single and multi-linear regression analysis [42-46]. Hammett equation employed, for the correlation analysis, involving the absorption maxima is as shown below in equation 1 .

$$
\lambda=\rho \sigma+\lambda_{0}
$$

Where $\lambda_{\mathrm{o}}$ is the frequency for the parent member of the series.

Table 2. The ultraviolet absorption maxima $(\lambda \max , \mathrm{nm})$, infrared absorptions $\left(\mathrm{v}, \mathrm{cm}^{-1}\right)$ and NMR chemical shifts $(\delta, \mathrm{ppm})$ of substituted N-benzylidinepyridine-2-amine.

\begin{tabular}{|c|c|c|c|c|c|}
\hline Entry & $\mathbf{X}$ & $\boldsymbol{\lambda}_{\mathbf{m a x}}$ & $\boldsymbol{v} \mathbf{C}=\mathbf{N}$ & $\boldsymbol{\delta} \mathbf{C H}=\mathbf{N}$ & $\boldsymbol{\delta} \mathbf{C}=\mathbf{N}$ \\
\hline $\mathbf{1}$ & $\mathrm{H}$ & 303.18 & 1598.99 & 9.124 & 158.28 \\
\hline $\mathbf{2}$ & $4-\mathrm{Br}$ & 308.81 & 1600.92 & 9.120 & 160.73 \\
\hline $\mathbf{3}$ & $3-\mathrm{Cl}$ & 310.27 & 1593.2 & 9.125 & 161.32 \\
\hline $\mathbf{4}$ & $2-\mathrm{F}$ & 311.90 & 1597.06 & 8.996 & 161.90 \\
\hline $\mathbf{5}$ & $4-\mathrm{F}$ & 318.16 & 1598.99 & 9.151 & 161.43 \\
\hline $\mathbf{6}$ & $4-\mathrm{CH}_{3}$ & 342.50 & 1595.13 & 9.104 & 162.95 \\
\hline $\mathbf{7}$ & $2-\mathrm{OCH}_{3}$ & 329.99 & 1597.06 & 9.552 & 159.15 \\
\hline $\mathbf{8}$ & $4-\mathrm{OCH}_{3}$ & 310.27 & 1597.06 & 9.112 & 160.79 \\
\hline $\mathbf{9}$ & $4-\mathrm{NO}_{2}$ & 305.01 & 1600.92 & 9.295 & 160.17 \\
\hline
\end{tabular}

The results of statistical analysis [42-46] of these values with Hammett substituent constants are presented in Table 3. From Table 3, it is evident that Hammett $\sigma, \sigma^{+}, \sigma_{R}$ and R constants give satisfactory correlations with $\lambda_{\max }$. All constants give positive $\rho$ values. The failure of some correlations with $\sigma_{\mathrm{I}}$ and $\mathrm{F}$ are due to the fact that the inductive and filed effects of the substituents are insufficient for predicting the reactivity on the absorption through conjugation. This is attributed to the resonance conjugative structure shown in Fig.1. 
Table 3. Results of statistical analysis of $\mathrm{UV} \lambda_{\max }(\mathrm{nm}), v \mathrm{C}=\mathrm{N}\left(\mathrm{cm}^{-1}\right) \mathrm{IR}, \mathrm{NMR} \delta^{1} \mathrm{H}(\mathrm{ppm}) \mathrm{CH}=\mathrm{N}$ and $\delta^{13} \mathrm{C}(\mathrm{ppm}) \mathrm{C}=\mathrm{N}$ of of substituted benzylidenepyridine-2-amine.

\begin{tabular}{|c|c|c|c|c|c|c|c|}
\hline Frequency & Constants & $\mathrm{r}$ & $\mathrm{I}$ & $\rho$ & $\mathrm{S}$ & $\mathrm{n}$ & Correlated derivatives \\
\hline \multirow[t]{6}{*}{$\lambda \max$} & $\sigma$ & 0.905 & 317.518 & -21.239 & 11.24 & 6 & 4-Br, 3-Cl, 2-F, 4-F, 2-OCH $3,4-\mathrm{NO}_{2}$. \\
\hline & $\sigma^{+}$ & 0.904 & 316.269 & -12.553 & 11.93 & 6 & 4-Br, 3-Cl, 2-F, 4-F, 2-OCH $3,4-\mathrm{NO}_{2}$. \\
\hline & $\sigma_{\mathrm{I}}$ & 0.809 & 323.997 & -23.837 & 12.33 & 9 & $\mathrm{H}, 4-\mathrm{Br}, 3-\mathrm{Cl}, 2-\mathrm{F}, 4-\mathrm{F}, 4-\mathrm{CH}_{3}, 2-\mathrm{OCH}_{3}, 4-\mathrm{OCH}_{3}, 4-\mathrm{NO}_{2}$. \\
\hline & $\sigma_{\mathrm{R}}$ & 0.903 & 311.429 & -16.824 & 12.99 & 8 & $\mathrm{H}, 4-\mathrm{Br}, 3-\mathrm{Cl}, 2-\mathrm{F}, 4-\mathrm{F}, 2-\mathrm{OCH}_{3}, 4-\mathrm{OCH}_{3}, 4-\mathrm{NO}_{2}$. \\
\hline & $\mathrm{F}$ & 0.833 & 321.785 & -15.371 & 12.95 & 9 & $\mathrm{H}, 4-\mathrm{Br}, 3-\mathrm{Cl}, 2-\mathrm{F}, 4-\mathrm{F}, 4-\mathrm{CH}_{3}, 2-\mathrm{OCH}_{3}, 4-\mathrm{OCH}_{3}, 4-\mathrm{NO}_{2}$. \\
\hline & $\mathrm{R}$ & 0.902 & 311.469 & -13.547 & 13.15 & 7 & $\mathrm{H}, 4-\mathrm{Br}, 3-\mathrm{Cl}, 2-\mathrm{F}, 4-\mathrm{F}, 4-\mathrm{OCH}_{3}, 4-\mathrm{NO}_{2}$. \\
\hline \multirow[t]{6}{*}{$v \mathrm{C}=\mathrm{N}$} & $\sigma$ & 0.731 & 1597.50 & 0.895 & 2.59 & 9 & $\mathrm{H}, 4-\mathrm{Br}, 3-\mathrm{Cl}, 2-\mathrm{F}, 4-\mathrm{F}, 4-\mathrm{CH}_{3}, 2-\mathrm{OCH}_{3}, 4-\mathrm{OCH}_{3}, 4-\mathrm{NO}_{2}$. \\
\hline & $\sigma^{+}$ & 0.829 & 1597.63 & 0.874 & 2.61 & 9 & $\mathrm{H}, 4-\mathrm{Br}, 3-\mathrm{Cl}, 2-\mathrm{F}, 4-\mathrm{F}, 4-\mathrm{CH}_{3}, 2-\mathrm{OCH}_{3}, 4-\mathrm{OCH}_{3}, 4-\mathrm{NO}_{2}$. \\
\hline & $\sigma_{\mathrm{I}}$ & 0.903 & 1596.45 & 1.581 & 2.57 & 7 & 4-Br, 2-F, 4-F, 4- $\mathrm{CH}_{3}, 2-\mathrm{OCH}_{3}, 4-\mathrm{OCH}_{3}, 4-\mathrm{NO}_{2}$. \\
\hline & $\sigma_{\mathrm{R}}$ & 0.802 & 1598.41 & 1.271 & 2.62 & 9 & $\mathrm{H}, 4-\mathrm{Br}, 3-\mathrm{Cl}, 2-\mathrm{F}, 4-\mathrm{F}, 4-\mathrm{CH}_{3}, 2-\mathrm{OCH}_{3}, 4-\mathrm{OCH}_{3}, 4-\mathrm{NO}_{2}$. \\
\hline & $\mathrm{F}$ & 0.809 & 1596.61 & 1.567 & 2.60 & 9 & $\mathrm{H}, 4-\mathrm{Br}, 3-\mathrm{Cl}, 2-\mathrm{F}, 4-\mathrm{F}, 4-\mathrm{CH}_{3}, 2-\mathrm{OCH}_{3}, 4-\mathrm{OCH}_{3}, 4-\mathrm{NO}_{2}$. \\
\hline & $\mathrm{R}$ & 0.823 & 1598.38 & 1.362 & 2.65 & 9 & $\mathrm{H}, 4-\mathrm{Br}, 3-\mathrm{Cl}, 2-\mathrm{F}, 4-\mathrm{F}, 4-\mathrm{CH}_{3}, 2-\mathrm{OCH}_{3}, 4-\mathrm{OCH}_{3}, 4-\mathrm{NO}_{2}$. \\
\hline \multirow[t]{6}{*}{$\delta \mathrm{CH}=\mathrm{N}$} & $\sigma$ & 0.803 & 9.184 & 0.057 & 0.166 & 9 & $\mathrm{H}, 4-\mathrm{Br}, 3-\mathrm{Cl}, 2-\mathrm{F}, 4-\mathrm{F}, 4-\mathrm{CH}_{3}, 2-\mathrm{OCH}_{3}, 4-\mathrm{OCH}_{3}, 4-\mathrm{NO}_{2}$. \\
\hline & $\sigma^{+}$ & 0.876 & 9.179 & 0.055 & 0.166 & 9 & $\mathrm{H}, 4-\mathrm{Br}, 3-\mathrm{Cl}, 2-\mathrm{F}, 4-\mathrm{F}, 4-\mathrm{CH}_{3}, 2-\mathrm{OCH}_{3}, 4-\mathrm{OCH}_{3}, 4-\mathrm{NO}_{2}$. \\
\hline & $\sigma_{\mathrm{I}}$ & 0.807 & 9.156 & 0.105 & 0.171 & 9 & $\mathrm{H}, 4-\mathrm{Br}, 3-\mathrm{Cl}, 2-\mathrm{F}, 4-\mathrm{F}, 4-\mathrm{CH}_{3}, 2-\mathrm{OCH}_{3}, 4-\mathrm{OCH}_{3}, 4-\mathrm{NO}_{2}$. \\
\hline & $\sigma_{\mathrm{R}}$ & 0.801 & 9.148 & 0.082 & 0.169 & 9 & $\mathrm{H}, 4-\mathrm{Br}, 3-\mathrm{Cl}, 2-\mathrm{F}, 4-\mathrm{F}, 4-\mathrm{CH}_{3}, 2-\mathrm{OCH}_{3}, 4-\mathrm{OCH}_{3}, 4-\mathrm{NO}_{2}$. \\
\hline & $\mathrm{F}$ & 0.799 & 9.193 & 0.103 & 0.171 & 9 & $\mathrm{H}, 4-\mathrm{Br}, 3-\mathrm{Cl}, 2-\mathrm{F}, 4-\mathrm{F}, 4-\mathrm{CH}_{3}, 2-\mathrm{OCH}_{3}, 4-\mathrm{OCH}_{3}, 4-\mathrm{NO}_{2}$. \\
\hline & $\mathrm{R}$ & 0.800 & 9.174 & 0.088 & 0.171 & 9 & $\mathrm{H}, 4-\mathrm{Br}, 3-\mathrm{Cl}, 2-\mathrm{F}, 4-\mathrm{F}, 4-\mathrm{CH}_{3}, 2-\mathrm{OCH}_{3}, 4-\mathrm{OCH}_{3}, 4-\mathrm{NO}_{2}$. \\
\hline \multirow[t]{6}{*}{$\delta \mathrm{C}=\mathrm{N}$} & $\sigma$ & 0.809 & 160.715 & 0.518 & 1.503 & 9 & $\mathrm{H}, 4-\mathrm{Br}, 3-\mathrm{Cl}, 2-\mathrm{F}, 4-\mathrm{F}, 4-\mathrm{CH}_{3}, 2-\mathrm{OCH}_{3}, 4-\mathrm{OCH}_{3}, 4-\mathrm{NO}_{2}$. \\
\hline & $\sigma^{+}$ & 0.709 & 160.736 & 0.504 & 1.505 & 9 & $\mathrm{H}, 4-\mathrm{Br}, 3-\mathrm{Cl}, 2-\mathrm{F}, 4-\mathrm{F}, 4-\mathrm{CH}_{3}, 2-\mathrm{OCH}_{3}, 4-\mathrm{OCH}_{3}, 4-\mathrm{NO}_{2}$. \\
\hline & $\sigma_{\mathrm{I}}$ & 0.900 & 160.539 & 0.923 & 1.501 & 7 & $\mathrm{H}, 4-\mathrm{Br}, 3-\mathrm{Cl}, 2-\mathrm{F}, 4-\mathrm{F}, 2-\mathrm{OCH}_{3}, 4-\mathrm{OCH}_{3}$. \\
\hline & $\sigma_{\mathrm{R}}$ & 0.801 & 160.554 & 0.725 & 1.495 & 9 & $\mathrm{H}, 4-\mathrm{Br}, 3-\mathrm{Cl}, 2-\mathrm{F}, 4-\mathrm{F}, 4-\mathrm{CH}_{3}, 2-\mathrm{OCH}_{3}, 4-\mathrm{OCH}_{3}, 4-\mathrm{NO}_{2}$. \\
\hline & $\mathrm{F}$ & 0.924 & 160.249 & 0.880 & 1.462 & 8 & $\mathrm{H}, 4-\mathrm{Br}, 3-\mathrm{Cl}, 2-\mathrm{F}, 4-\mathrm{F}, 2-\mathrm{OCH}_{3}, 4-\mathrm{OCH}_{3}, 4-\mathrm{NO}_{2}$. \\
\hline & $\mathrm{R}$ & 0.806 & 160.345 & 0.750 & 1.468 & 9 & $\mathrm{H}, 4-\mathrm{Br}, 3-\mathrm{Cl}, 2-\mathrm{F}, 4-\mathrm{F}, 4-\mathrm{CH}_{3}, 2-\mathrm{OCH}_{3}, 4-\mathrm{OCH}_{3}, 4-\mathrm{NO}_{2}$. \\
\hline
\end{tabular}
$\mathrm{r}=$ correlation co-efficient; $\rho=$ slope; $\mathrm{I}=$ intercept; $\mathrm{s}=$ standard deviation; $\mathrm{n}=$ number of substituent

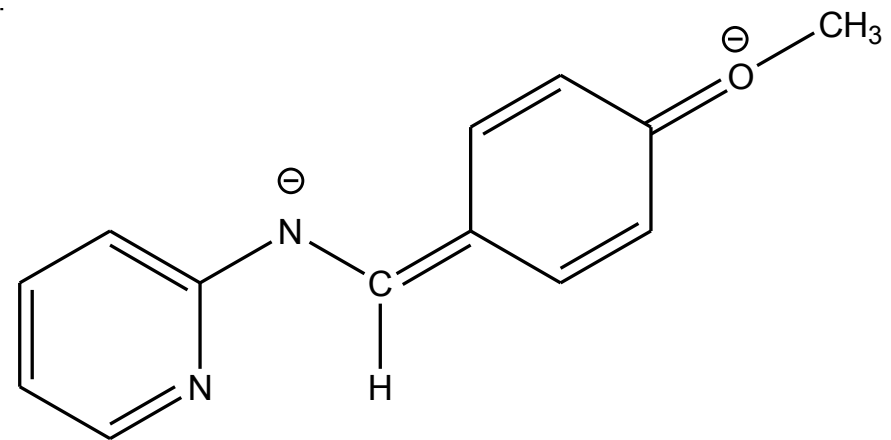

Fig. 1. The resonance - conjugated structure.

The multi-regression analysis of these UV spectral data of all imines with inductive, resonance and Swain - Lupton's [47] constants produce satisfactory correlations as shown in equations 2 and 3.

$$
\begin{gathered}
\lambda_{\max }{ }^{(\mathrm{nm})}=319.87( \pm 8.270)-25.950( \pm 11.937) \sigma_{\mathrm{I}}-19.382( \pm 7.055) \sigma_{\mathrm{R}} \\
(R=0.958, n=9, \mathrm{P}>95 \%) \\
\lambda_{\max }{ }^{(\mathrm{nm})}=318.023( \pm 8.128)-21.873( \pm 10.587) \mathrm{F}-20.577( \pm 6.728)_{\mathrm{R}} \\
(R=0.954, n=9, P>95 \%)
\end{gathered}
$$




\section{1. 2. IR Spectral study}

The infrared $v \mathrm{C}=\mathrm{N}$ stretching frequencies $\left(\mathrm{cm}^{-1}\right)$ of the synthesized imines have been recorded and presented in Table-2. These data are correlated [42-46] with Hammett substituent constants and Swain-Lupton's [47] parameters. In this correlation the structure parameter Hammett equation employed is as shown in equation (4).

$$
v=\rho \sigma+v_{\mathrm{o}}
$$

Where $v_{0}$ is the frequency for the parent member of the series.

The assigned $v \mathrm{C}=\mathrm{N}$ stretching frequencies $\left(\mathrm{cm}^{-1}\right)$ are correlated with various Hammett substituent constants and $\mathrm{F}$ and $\mathrm{R}$ parameters through single and multi-regression analyses including Swain-Lupton's [47] parameters. The results of statistical analysis of single parameter correlation are shown in Table-3. The correlation of $\nu \mathrm{C}=\mathrm{N}\left(\mathrm{cm}^{-1}\right)$ frequencies of imines with Hammett $\sigma_{I}$ constant is satisfactorily. The remaining Hammett constants, $\mathrm{F}$ and $\mathrm{R}$ parameters were found to be fail in correlation with positive $\rho$ value. This is due to the absence of polar, field, resonance and inductive effects of the substituents are unable to predict the reactivity on $\mathrm{C}=\mathrm{N}$ stretches. This is associated with the conjugative structure shown in Fig.1. So, the authors think that it is worthwhile to seek the multi regression analysis which may produce a satisfactory correlation with Resonance, Field and SwainLupton's [47] constants. This is shown in the following equations 5 and 6.

$$
\begin{aligned}
& v_{\mathrm{C}=\mathrm{N}}{ }^{(\mathrm{cm}-1)}=1597.136( \pm 1.791)+3.927( \pm 1.885) \sigma_{\mathrm{I}}+3.215( \pm 1.694) \sigma_{\mathrm{R}} \\
& (R=0.946, \mathrm{n}=9, \mathrm{P}>95 \%) \\
& v_{\mathrm{C}=\mathrm{N}}{ }^{(\mathrm{cm}-1)}=1597.241( \pm 1.697)+3.802( \pm 1.463) \mathrm{F}+3.413( \pm 1.493) \mathrm{R} \\
& (R=0.946, \mathrm{n}=9, \mathrm{P}>95 \%)
\end{aligned}
$$

\section{1. 3. ${ }^{1} \mathrm{H}$ NMR Spectral study}

The ${ }^{1} \mathrm{H}$ NMR spectra of the imine derivatives under investigation have been recorded in deuteriochloroform solution employing tetramethylsilane (TMS) as internal standard. The signals of the imine protons have been assigned and are presented in Table 2. In nuclear magnetic resonance spectra, the ${ }^{1} \mathrm{H}$ or the ${ }^{13} \mathrm{C}$ chemical shifts $(\delta, \mathrm{ppm})$ depend on the electronic environment of the nuclei concerned. These chemical shifts have been correlated with reactivity parameters. Thus the Hammett equation has been used in the form as shown in (7).

$$
\delta=\delta_{0}+\rho \sigma
$$

where $\delta_{0}$ is the chemical shift of the corresponding parent compound.

The assigned proton chemical shifts (ppm) of imines have been correlated [26-30] with various Hammett sigma constants, $\mathrm{F}$ and $\mathrm{R}$ parameters. The results of statistical analysis are presented in Table 3. These proton chemical shifts $(\mathrm{ppm})$ fail in correlation with Hammett substituent constants, F and R parameters. All correlations gave positive $\rho$ values. This shows that the normal substituent effect operates in all systems. The failure in correlation is attributed to the conjugative structure shown in Fig. 1. The authors think that, it is worthwhile 
to seek multiple correlations involving either $\sigma_{\mathrm{I}}$ and $\sigma_{\mathrm{R}}$ constants or Swain- Lupton's [47], F and $\mathrm{R}$ parameters. This is shown in the following equations 8 and 9.

$$
\begin{gathered}
\delta_{\mathrm{CH}}{ }^{(\mathrm{ppm})}=9.134( \pm 0.124)+0.041( \pm 0.070) \sigma_{\mathrm{I}}-0.103( \pm 0.057) \sigma_{\mathrm{R}} \\
(R=0.917, n=9, \quad P>90 \%) \\
\delta_{\mathrm{CH}}{ }^{(\mathrm{ppm})}=9.189\left(\begin{array}{c} 
\pm 0.120)-0.052( \pm 0.044) \mathrm{F}-0.021( \pm 0.047) \mathrm{R} \\
(R=0.908, \mathrm{n}=9, \mathrm{P}>90 \%)
\end{array}\right.
\end{gathered}
$$

\section{1. 3. ${ }^{13} \mathrm{C}$ NMR spectra}

Physical organic chemists and researchers [42-46], have made extensive study of ${ }^{13} \mathrm{C}$ NMR spectra for a large number of ketones, styrenes, styryl ketones and keto-epoxides. They have studied linear correlation of the chemical shifts (ppm) of $\mathrm{C}_{\alpha}, \mathrm{C}_{\beta}$ and $\mathrm{CO}$ carbons with Hammett $\sigma$ constants in alkenes, alkynes, acid chlorides and styrenes. In the present study, the chemical shifts (ppm) of imine $\mathrm{C}=\mathrm{N}$ carbon, have been assigned and are presented in Table 2. Attempts have been made to correlate the $\delta \mathrm{C}=\mathrm{N}$ chemical shifts (ppm) with Hammett substituent constants, field and resonance parameters, with the help of single and multi-regression analyses to study the reactivity through the effect of substituents.

The chemical shifts (ppm) observed for the $\delta \mathrm{C}=\mathrm{N}$ have been correlated [26-30], with Hammett constants and the results of statistical analysis are presented in Table 3 . The $\delta \mathrm{C}=\mathrm{N}$ chemical shifts $(\mathrm{ppm})$ give satisfactory correlation with Hammett constant $\sigma_{\mathrm{I}}$, and $\mathrm{F}$ parameter. The remaining substituent constants and $\mathrm{R}$ values are failing in correlation. This due to the reasons stated earlier and it is associated with the conjugated structure shown in Fig. 1. The authors think that it is worthwhile to seek multiple correlation involving all $\sigma_{\mathrm{I}}, \sigma_{\mathrm{R}}$, $\mathrm{F}$ and $\mathrm{R}$ parameters. This is given in the following correlation equations 10 and 11.

$$
\begin{gathered}
\delta_{\mathrm{C}=\mathrm{N}}{ }^{(\mathrm{ppm})}=163.387( \pm 1.101)+0.513( \pm 0.388) \sigma_{\mathrm{I}}-0.712( \pm 0.271) \sigma_{\mathrm{R}} \\
(R=0.916, \quad n=9, \quad P>92 \%) \\
\delta_{\mathrm{C}=\mathrm{N}}{ }^{(\mathrm{ppm})}=160.066( \pm 1.006)+0.930( \pm 0.054) \mathrm{F}-1.001( \pm 0.072) \mathrm{R} \\
(R=0.931, \quad n=9, \quad P>94 \%)
\end{gathered}
$$

\section{2. Microbial activities}

\section{2. 1. Antibacterial sensitivity assay}

Antibacterial sensitivity assay has been performed by using disc diffusion [39] technique. In each Petri plate about $0.5 \mathrm{ml}$ of the test bacterial sample has been spread uniformly over the solidified Mueller Hinton agar using sterile glass spreader. Then the discs with $5 \mathrm{~mm}$ diameter made up of Whatmann No.1 filter paper, impregnated with the solution of the compound have been placed on the medium using sterile forceps. The plates have been incubated for 24 hours at $37{ }^{\circ} \mathrm{C}$ by keeping the plates upside down to prevent the collection of water droplets over the medium. After 24 hours, the plates have been visually examined and the diameter values of the zone of inhibition were measured. Triplicate results have been recorded by repeating the same procedure.

The antibacterial screening effect of synthesized Schiff's bases is shown in Figure 2 (Plates 1-10). The antibacterial activities of all the synthesized imines have been studied against three gram positive pathogenic strains Micrococcus luteus, Bacillus substilis, Staphylococcus aureus and two gram negative strains Escherichia coli and P.aeruginosa.

The disc diffusion technique was followed at a concentration of $250 \mu \mathrm{g} / \mathrm{mL}$ with Ampicillin taken as the standard drug. 


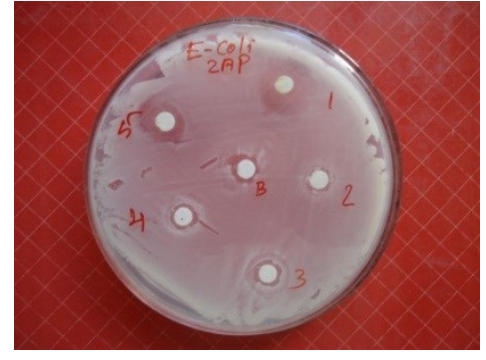

PLATE-1

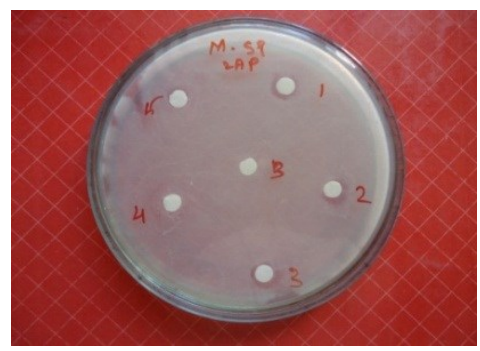

PLATE-3

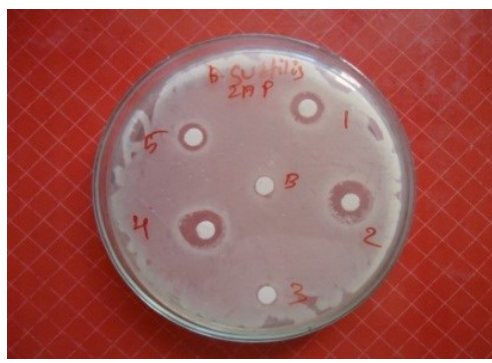

PLATE-5

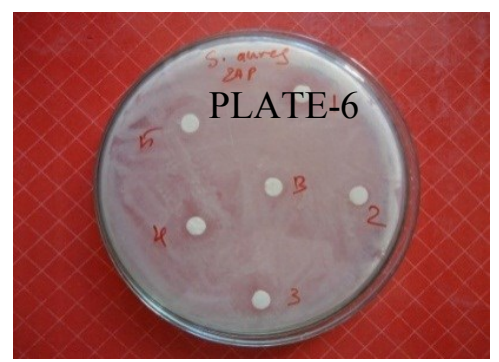

PLATE-7

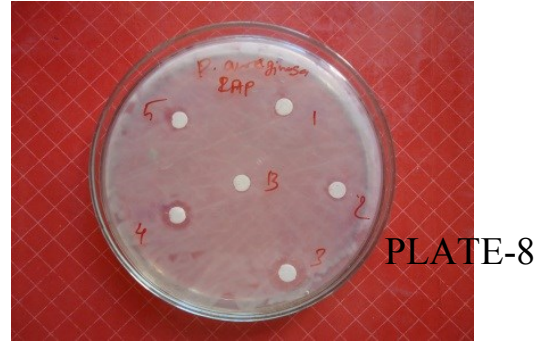

PLATE-9

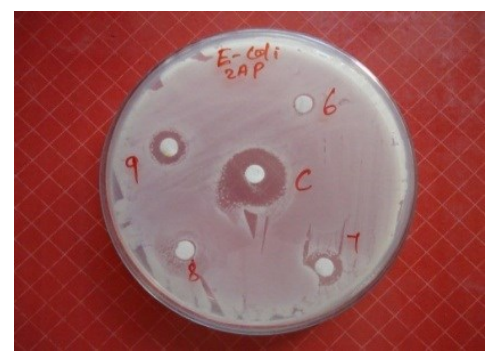

PLATE-2

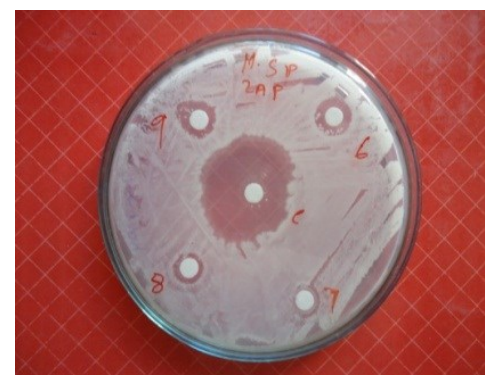

PLATE-4

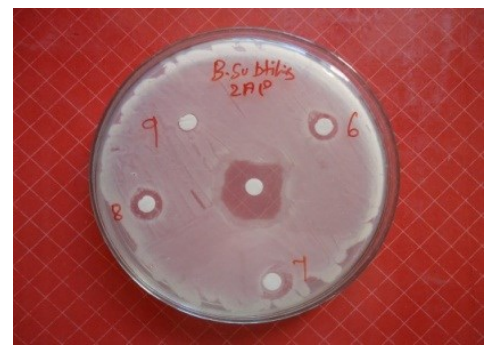

PLATE-6

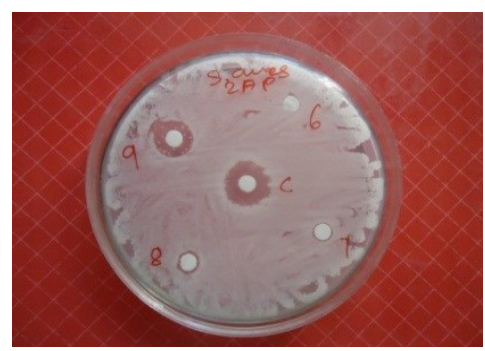

PLATE-8

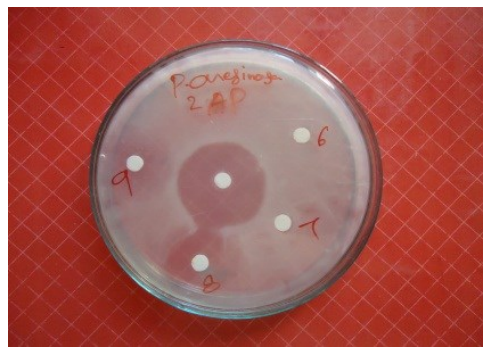

PLATE-10

Figure 2. Antibacterial activity of substituted Benzylidenepyridine-2-amines petri-dishes. 
The zone of inhibition is compared using Table 4 and the corresponding clustered column chart is shown in Fig. 3. A good antibacterial activity has been possessed by all substituents on the microorganisms in general. The substituents 4- $\mathrm{Br}, 3-\mathrm{Cl}, 2-\mathrm{OCH}_{3}$ and 4$\mathrm{OCH}_{3}$ have very good activity against Bacillus substilis. The substituents 4-Br, 2-F and 4$\mathrm{OCH}_{3}$ have improved antibacterial activity against Micrococcus luteus. The substituents 4$\mathrm{CH}_{3}$ have very good activity against Staphylococcus aureus. The substituents 2-F and 2$\mathrm{OCH}_{3}$ have moderate activity against Escherichia coli and P.aeruginosa.

Table 4. Antibacterial activity of substituted benzylidenepyridine-2-amines.

\begin{tabular}{|c|c|c|c|c|c|c|}
\hline \multirow{2}{*}{ Entry } & \multirow{2}{*}{$\mathbf{X}$} & \multicolumn{5}{|c|}{ Zone of Inhibition (mm) } \\
\cline { 2 - 7 } & & \multicolumn{2}{|c|}{ Gram positive Bacteria } & \multicolumn{2}{c|}{ Gram negative Bacteria } \\
\cline { 2 - 7 } & B.subtilis & M.luteus & S.aureus & E.Coli & P.aeruginosa \\
\hline $\mathbf{1}$ & $\mathrm{H}$ & 7 & 7 & 8 & 7 & 8 \\
\hline $\mathbf{2}$ & $4-\mathrm{Br}$ & 9 & 8 & 7 & - & 7 \\
\hline $\mathbf{3}$ & $3-\mathrm{Cl}$ & 8 & - & - & 7 & 7 \\
\hline $\mathbf{4}$ & $2-\mathrm{F}$ & - & 8 & 7 & 9 & 10 \\
\hline $\mathbf{5}$ & $4-\mathrm{F}$ & - & - & - & - & - \\
\hline $\mathbf{6}$ & $4-\mathrm{Me}$ & 7 & & 10 & 8 & 8 \\
\hline $\mathbf{7}$ & $2-\mathrm{OMe}$ & 8 & 7 & 8 & 8 & 9 \\
\hline $\mathbf{8}$ & $4-\mathrm{OMe}$ & 8 & 8 & - & - & 7 \\
\hline $\mathbf{9}$ & $4-\mathrm{NO} 2$ & 7 & 7 & 7 & 7 & 8 \\
\hline & AMPICILLIN & 16 & 19 & 14 & 17 & 13 \\
\hline & DMSO & - & - & - & - & - \\
\hline
\end{tabular}

\section{2. Antifungal sensitivity assay}

Antifungal sensitivity assay has been performed using disc diffusion technique [39] PDA medium was prepared and sterilized as above. It has been poured (ear bearing heating condition) in the Petri-plate which has been already filled with $1 \mathrm{ml}$ of the fungal species.

The plates have been rotated clockwise and counter clock-wise for uniform spreading of the species. The discs have been impregnated with the test solution. The test solution has been prepared by dissolving $15 \mathrm{mg}$ of the Schiff's bases in $1 \mathrm{ml}$ of DMSO solvent. The medium have been allowed to solidify and kept for 3 days.

Then the plates have been visually examined and the diameter values of zone of inhibition have been measured. Triplicate results have been recorded by repeating the same procedure.

The antifungal activities of substituted imines have been studied and are shown in Fig. 4. for Plates (11-14) and the zone of inhibition values of the effect is given in Table 5. 


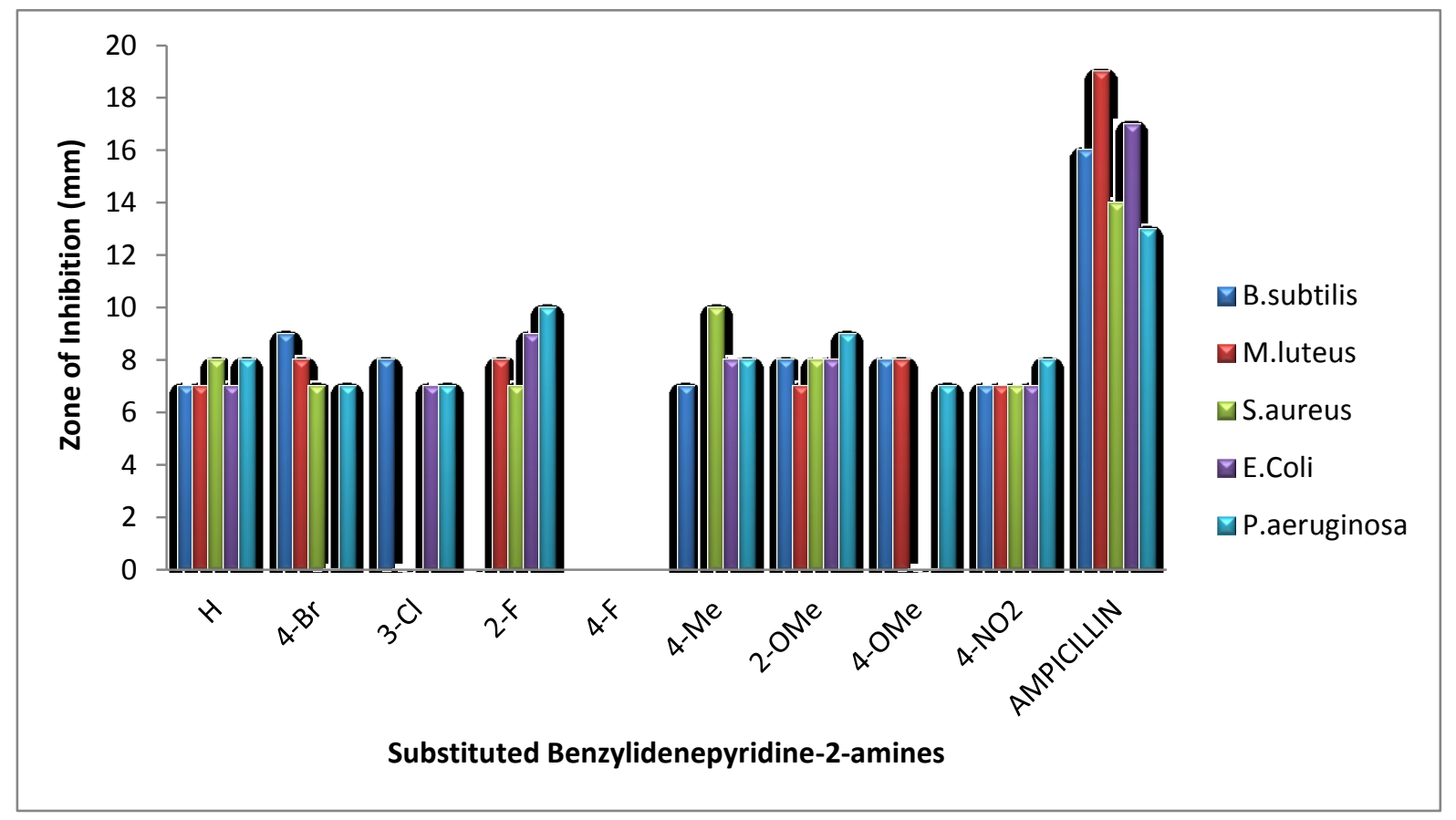

Figure 3. Antibacterial activity of substituted Benzylidenepyridine-2-amines.

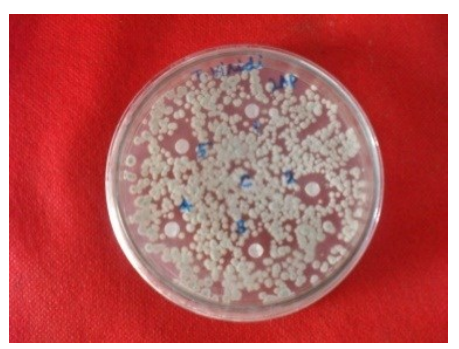

PLATE-11

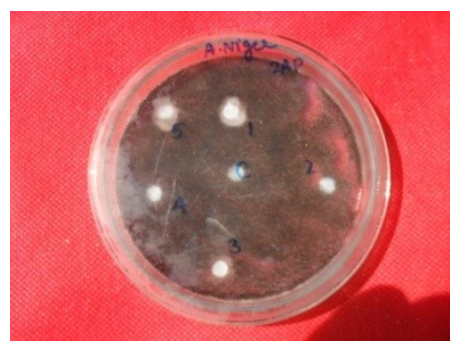

PLATE-13

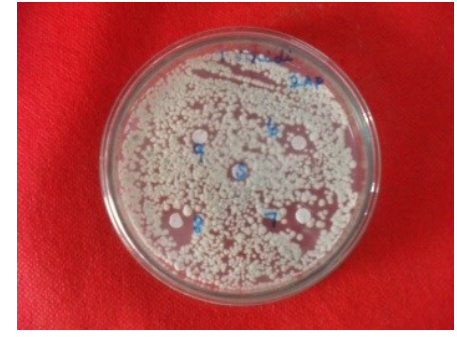

PLATE-12

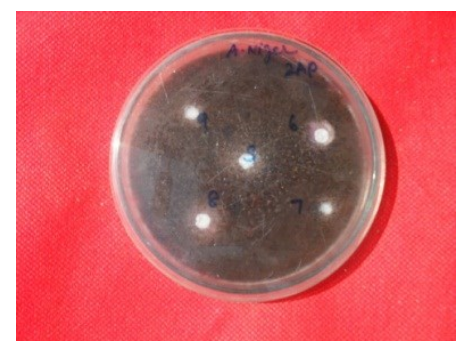

PLATE-14

Figure 4. Antifungal activity of substituted Benzylidenepyridine-2-amines petridishes.

The clustered column chart, shown in Fig 4. A good antifungal activity has been possessed by all substituents on the microorganisms in general. The substituents $4-\mathrm{Br}$ and $4-\mathrm{F}$ have improved activity against Tricodermaviridi. All the substituents except 4- $\mathrm{NO}_{2}$ have shown very good activity against Aspergillus niger. 
Table-5. Antifungal activity of substituted Benzylidenepyridine-2-amines.

\begin{tabular}{|c|c|c|c|}
\hline \multirow{2}{*}{ Entry } & \multirow{2}{*}{$\mathbf{X}$} & \multicolumn{2}{c|}{ Zone of Inhibition (mm) } \\
\cline { 2 - 4 } & & A.niger & T.Viridi \\
\hline $\mathbf{1}$ & $\mathrm{H}$ & - & 11 \\
\hline $\mathbf{2}$ & $4-\mathrm{Br}$ & 6 & 11 \\
\hline $\mathbf{3}$ & $3-\mathrm{Cl}$ & - & 11 \\
\hline $\mathbf{4}$ & $2-\mathrm{F}$ & 8 & 12 \\
\hline $\mathbf{5}$ & $4-\mathrm{F}$ & 9 & 10 \\
\hline $\mathbf{6}$ & $4-\mathrm{Me}$ & 9 & 10 \\
\hline $\mathbf{7}$ & 2-OMe & - & 10 \\
\hline $\mathbf{8}$ & 4-OMe & 8 & 10 \\
\hline $\mathbf{9}$ & 4-NO & 13 & 8 \\
\hline & MICONAZOLE & - & 14 \\
\hline & DMSO & & - \\
\hline
\end{tabular}

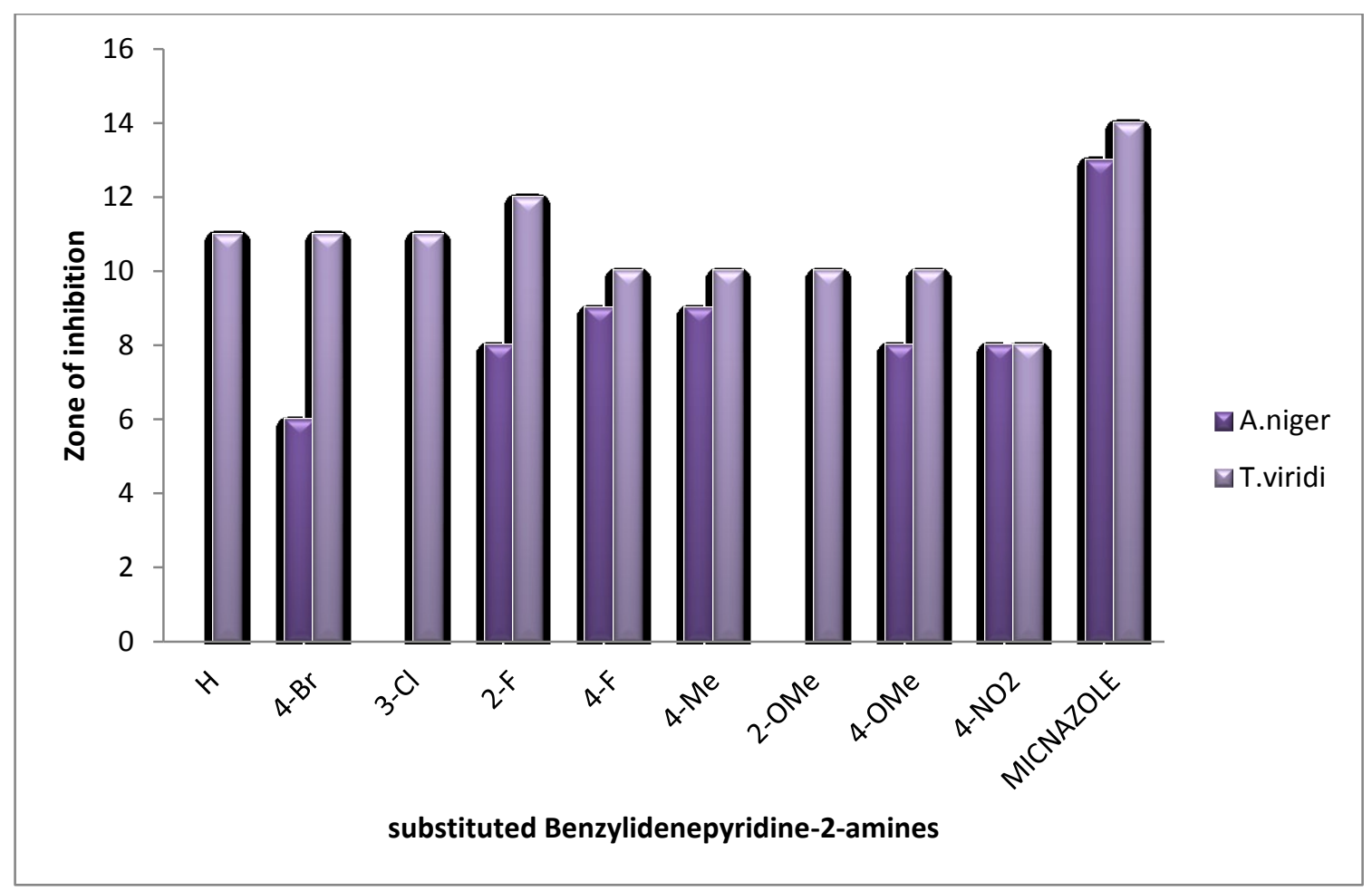

Figure 5. Antifungal activity of substituted Benzylidenepyridine-2-amines. 


\section{CONCLUSION}

Some Schiff's bases have been synthesized by condensation of amines and benzaldehydes using microwave irradiation in the presence of Fly-ash: PTS under solvent free conditions. This reaction protocol offers a simple, eco-friendly; non-hazardous, easier work-up procedure and good yields. These Schiff's bases have been characterized by their physical constants, spectral data. The UV, IR, NMR spectral data of these imines has been correlated with Hammett substituent constants, F and R parameters. From the results of statistical analyses the effects of substituent on the spectral data have been studied. The antimicrobial activities of all synthesized imines have been studied using Bauer-Kirby method.

\section{ACKNOWLEDGEMENT}

The authors thank DST NMR facility, Department of Chemistry, Annamalai University, Annamalainagar-608 002, for recording NMR spectra of all compounds.

\section{References}

[1] Lau K., Mayr Y., Cheung A., Inorg. Chim. Acta. 285 (1999) 223-225.

[2] Schiff H., Ann. Chem. 1311864 118-119.

[3] Moffett R. B., Rabjohn N., Editor, Organic Synthesis; John Wiley \& Sons, Inc., New York 4 (1963) 605-608.

[4] Macho V., Kralik M., Hudec J., Cingelova J., J. Mol. Catal. A: Chem. 209 (2004) 69-73.

[5] Bey P., Vevert J. P., Tetrahedron Lett. 18 (1977) 1455-1458.

[6] Fleet G. W. J., Fleming I., J. Chem. Soc. (1969) 1758-1763.

[7] Adams J. P., J. Chem. Soc. Perkin Trans. 1 (2000) 125-139.

[8] Jungreis E., Thabet S., Marcell Dekker., "Analytical Applications of Schiff bases", New York.7 (1969) 149-177.

[9] Croot P. L., Johansson M., Electroanalysis 12 (2000) 565-576.

[10] Choi D., Lee S. K., Chung T. D., Kim H., Electroanalysis 12 (2000) 477-482.

[11] Raman N., Muthuraj., Ravichandran V., Kulandaisamy S., A. J. Chem. Sci. 115 (2003) 161-167.

[12] Gupta K. C., Sutar A. K., Coord. Chem. Rev 252 (2008) 1420-1450.

[13] Yuan M., Zhao F., Zhang W., Wang Z. M., Gao S., Inorg. Chem 46 (2007) 1123511242.

[14] Fukuda H., Amimoto K., Koyama H., Kawato T., Tetrahedron Lett. 50 (2009) 53765378.

[15] Liu Y. C., Yang C. Y., Inorg. Chem.Commun 12 (2009) 704-709.

[16] Leung A. C. W., MacLachlan M. J., J. Inorg. Organomet. Polym Mate 17 (2007) 5789. 
[17] Zishen W., Zhiping L., Zhenhuan Y., Transit. Met. Chem 18 (1993) 291-294.

[18] Nejati K., Rezvani Z., Massoumi B., Dyes Pigment. 75 (2007) 653-657.

[19] Naderi E., Jafari A. H., Ehteshamzadeh M., Hosseini M. G., Met. Chem. Phys. 115 (2006) 852-858.

[20] Sriram D., Yogeeswari P., Myneedu N S., Saraswat V., BioorgMed. Chem. Lett 16 (2006) 2127-2129.

[21] Stilinovic V., Cincic D., Kaitner B., Acta. Chim. Slov 55 (2008) 874-879.

[22] Popp. F. D., J. Org. Chem. 26 (1961) 1566-1568.

[23] Rao X., Huang X., He L., Song J., Song Z., Shang S., Comb. Chem. High Throughput. Screen. 15 (2012) 840-844.

[24] Hadjipavlou-litina D. J., Geronikaki A. A., Drug Des. Discov. 15 (1996) 199-206.

[25] Tiwary M., Naik S. N., Tiwari D. K., Mittal P. K., Yadav S., J. Vect. Brone Dis. 44 (2007) 198-204.

[26] Venugopala K. N., Jayashree V., A. Indian J. Pharm. Sci. 70 (2008) 88-90.

[27] Solak N., Rollas S., Arkivoc, xii (2006) 173-181.

[28] Wadher S. J., Puranik M. P., Karande N. A., Yeole P. G., Int. J. Pharm. Tech. Res. 1 (2009) 22-33.

[29] Cates A. L., Rasheed S. M., Pharm. Res. 6 (1984) 271-273.

[30] Kuznetsov V. V., Palma A. R., Aliev A. E., Varlamov A. V., Prostakov N. S., Zh. Org. Khim. 127 (1991) 1579-1581.

[31] Taggi A., EHafez A. M., Wack H., Young B., Ferrari D., Lectka T., J. Am. Chem. Soc. 124 (2002) 6626-6635.

[32] Tsuge O., Kanemasa R., Adv. Heterocycl. Chem. 45 (1989) 231-249.

[33] Owen N. L., Sultanbawa M. V. S., J. Chem. Soc. (1949) 3098-3105

[34] Kamalakkannan D., Vanangamudi G., Arulkumaran R., Thirumurthy K., Mayavel P., Thirunarayanan G., Elixir Org. Chem. 46 (2012) 8157-8166.

[35] Thirunarayanan G., Indian J. Chem. 46B (2007) 1551.

[36] Ranganathan K., Arulkumaran R., Kamalakkannan D., Vanangamudi G., Thirunarayanan G., Iup. J. Chem. 4(2) (2011) 60-70.

[37] Katritzky A. R., Wang M. Y., Zhang S. M., Vonkov A. V. V., Steel P. J., J. Org. Chem. 66 (2001) 6787-6791.

[38] Thirunarayanan G., Vanangamudi G., Sathiyendiran V., Ravi K., Indian J. Chem. 50(4) (2011) 593.

[39] Bauer A. W., Kirby W. M. M., Sherris J. C., Truck M., Am. J. Clin. Pathol. 45 (1996) 493-498.

[40] Sundararajan R., Arulkumaran R., Vijayakumar S., Kamalakkannan D., Suresh R., Ranganathan K., Sakthinathan S. P., Vanangamudi G., Thirumurthy K., Mayavel P., Thirunarayanan G., Int. J. Pharm. Chem. Sci. 1(4) (2012) 1657-1677.

[41] Hania M. M., E-Journal of Chemistry 6(3) (2009) 629-632. 
[42] Thirunarayanan G., Vanangamudi G., Spectrochim. Acta 81A (2011) 390-396.

[43] Thirunarayanan G., Gopalakrishnan M., Vanangamudi G., Spectrochim. Acta 67A (2007) 1106-1112.

[44] Jovanović B. Ž., Mišić-Vuković M., Marinković A. D., Vajs V., J. Mol. Struct. 642 (2002) 113-118.

[45] Echevarria.A, Nascimento M. G., Geronimo, V. Miller.J., Giesbrecht A., J. Braz. Chem. Soc. 10 (1999) 60-64.

[46] Fadhil G. F., Essa A. H., J. Iran Chem. Soc. 6 (2009) 808-811.

[47] Swain C. G., Lupton Jr. E. C., J. Am. Chem. Soc. 90 (1968) 4328-4337. 